Nicholas O'Shaughnessy, Marketing the Third Reich: Persuasion, Packaging and Propaganda (Abingdon, Routledge, 2018). - 29o pages. - IS BN 9781138060562.

Doubtlessly propaganda occupies a large role in the public consciousness of Nazi Germany, yet there are strikingly few comprehensive studies on this topic, at least in English. While there is no shortage of monographs on specific aspects of Nazi propaganda, such as its relationship to popular culture, cinema, or genocide, Marketing the Third Reich is a rare synthesis of the current state of research, with an unusual angle (for historians). Nicholas O'Shaughnessy, Professor of Communication at Queen Mary, University of London, is indeed not primarily an historian, but a scholar of political marketing who has branched out to investigate the 'engineering of consent' in the Third Reich.

O'Shaughnessy puts forward a self-consciously bold proposal: that not just Nazi propaganda, but the entirety of Nazi Germany can fruitfully be understood through the analytical framework of political marketing. Anticipating that the concept of marketing might seem anachronistic and even distastefully banal when applied to the Third Reich, O'Shaughnessy points to the early emergence of marketing research in interwar Germany, and the recognition of advertising techniques in Nazi propaganda by contemporaries like Victor Klemperer. The author argues the Nazis were forerunners of later politicians to rely on political marketing techniques, and indeed the final chapters of the book deal specifically with a comparison of Nazi Germany to modern democratic states in this regard.

The book is rigidly organised around key themes, with an uncommonly schematic approach in each chapter which most historians will probably find a little unusual, but works well enough. Each chapter introduces the argument and provides the historical context first, before highlighting neatly sub-titled aspects and case studies for the topic at hand, ending with a very brief conclusion. The chapters are divided across three parts, dealing with the Nazi 'brand' as such and its 'managers', its implementation by various means (the majority of the volume), and lastly its implications for the post-war world and the present. The final chapters deal specifically with how the image of the Nazis has survived in our own time, and attempts to answer the question whether Hitler was ahead of his time in terms of political self-presentation - an interesting question which O'Shaughnessy is certainly uniquely qualified to answer. There is also a brief epilogue on Hitler and Donald Trump, though inevitably the analysis already feels very dated indeed.

Across the chapters the author has three bold, interconnected, points to make. Firstly, 'that propaganda and political marketing existed not merely as 
an instrument of government, as with other regimes, but the very medium through which government governed' (p. 1). Nazi Germany, according to O'Shaughnessy, was ruled foremost through propaganda: every significant branch of the regime had a propaganda unit, every leading figure controlled some kind of propaganda operation. The logic of propaganda often trumped all other considerations, including ideological ones, and fundamentally shaped Hitler's thinking around government. Secondly then, Hitler was the centre of propaganda in Nazi Germany, not just as its subject, but as its director - not Goebbels or anyone else (p. 35). Thirdly, and most boldly, that persuasion is the core dynamic of history, or at least the history of the Third Reich: the regime operated to persuade its subjects via propaganda and marketing, by selling the Führer and his brand, and the concomitant dynamic dictated aesthetics, content, and policy (p. 2). While the Third Reich was a terroristic state, the author argues, unlike Stalin's regime it operated primarily through seduction, not coercion.

The end result of O'Shaughnessy's argument is not very unconventional. Marketing the Third Reich is heavily based on secondary literature, relying particularly on major works of the historiography such as Joachim Fest, Ian Kershaw, and the spate of research that has been published in English on various aspects of Nazi propaganda and popular culture. Unfortunately there is a clear gap in material from the German historiography here. There is also the occasional reference to fascism aside from Nazi Germany, which tends a little jarring as O'Shaughnessy does not appear to have explored the subject beyond Robert O. Paxton's quite dated Anatomy of Fascism (2004) - theories of fascism have come a long way since. The primary source basis is principally material from the online Calvin College German Propaganda Archive, the Goebbels diaries, Heinrich Hoffmann's photography, and the like, but not the German federal archives. With this basis, the book summarises and synthesises the material very well, and presents an accessible and unified account of propaganda in the Nazi movement and the Third Reich. Together with the extensive description of Nazi propaganda, long quotes from the sources, and the provisions of propaganda minutiae and statistics (but no graphs), it makes Marketing the Third Reich conceivably a useful teaching tool, a handy starting point for understanding propaganda in Nazi Germany.

The political marketing analysis does shed light on many elements of Nazi propaganda, or at least offers a refreshing perspective through which to understand it. Seeing symbols like the Swastika and Hitler's image as part of a brand, and the Nazis pursuing 'brand resonance' through a variety of innovative techniques is convincing (p. 17), with targeted advertising and anticipation of 
modern market research techniques (p. 59). The idea that 'packaging' in the commercial sense can be applied to a political party, an ideology, and its leader is insightful: 'The packaging carries an idealised and hyperbolic image of the core product. It is a prior, antecedent idea of the product which defines expectations and anticipates the consumption experience.' (p. 142) O'Shaughnessy's approach highlights the formulaic and calculated Nazi approaches to propaganda, and the tension with a search for new, innovative approaches to persuasion. But the idea of marketing at times stops working as a useful explanatory device, and instead becomes a seductive metaphor instead, elegant but not necessarily elucidating. However, marketing elements take a backseat surprisingly often, with a lot of the analysis returning to more familiar culturalist approaches. For instance the author insists strongly on the mystical aspects of Nazi leadership (p. 124), which meshes very poorly with the emphasis on marketing, giving the book something of a split character, part cultural-political, part political marketing analysis. Generally the book is stronger on the organisational and operational aspects of Third Reich propaganda: offices, techniques, power struggles, intentions - and weaker on the visual aspects of propaganda, such as art and architecture, or reception. O'Shaughnessy's reliance on 'hypodermic needle' theory - proposing audiences unresistingly accept messages as intended - does not take into account alternative hermeneutic frameworks through which audiences could critically receive Nazi propaganda, making it appear altogether indomitable.

Marketing the Third Reich is indeed one of few books to deal with Nazi propaganda comprehensively. In spite of its bold contestations much of this is familiar territory, especially to cultural historians, but rarely has it been brought together in such a unified and easily accessible manner. This book is at its most compelling when analysing the Nazis' covert propaganda in popular culture like magazines and cinema, where the argument of modern branding and marketing really comes into its own. As such it would fit nicely on many a university reading list, while scholars may find something refreshing in O'Shaughnessy's marketing take, even if the book does not always sell it as well as perhaps it could.

\section{Nathaniël Kunkeler}

University of Cambridge, Cambridge, United Kingdom

nk372@cam.ac.uk 